\title{
Survey of Medicinal Plants Used in the Treatment of "Ailments of Utmost Native Importance" in Cross River State, Nigeria
}

\author{
Vincent Tawo Ebu ${ }^{*}$, Regina Ado Anoh ${ }^{1}$, Raphael Ayama Offiong², Pauline Ayuk Essoka ${ }^{3}$ \\ ${ }^{1}$ Department of Forestry and Wildlife Resources Management, University of Calabar, Calabar, Nigeria \\ ${ }^{2}$ Department of Urban and Regional Planning, University of Calabar, Calabar Nigeria \\ ${ }^{3}$ Department of Geography and Environmental Science, University of Calabar, Calabar Nigeria \\ Email: ^ebutality@gmail.com, eriomregina@gmail.com,raphyxx5@gmail.com,pessoka@gmail.com
}

How to cite this paper: Ebu, V. T., Anoh, R. A., Offiong, R. A., \& Essoka, P. A. (2021). Survey of Medicinal Plants Used in the Treatment of "Ailments of Utmost Native Importance" in Cross River State, Nigeria. Open Journal of Forestry, 11, 330-339.

https://doi.org/10.4236/ojf.2021.113020

Received: April 6, 2021

Accepted: July 26, 2021

Published: July 29, 2021

Copyright $\odot 2021$ by author(s) and Scientific Research Publishing Inc. This work is licensed under the Creative Commons Attribution International License (CC BY 4.0).

http://creativecommons.org/licenses/by/4.0/

\begin{abstract}
Regardless of the high value of medicinal plants to residents of Cross River State in health maintenance especially for the treatment of "ailments of utmost native importance", the major constraint is the uncertainty of the availability of the herbs and knowledge of traditional medicine still being passed by word of mouth. For better reliance on the plant species as medicine, this research seeks to identify and infer on the population and distribution of the species used in their treatment and documents them. Data were collected using field work and oral interviews. The survey team comprised of Taxonomists, survey assistants, five trado-medical herbal practitioners and the Authors. The status and geographical distribution of the identified medicinal plant species was appalling, 59 percent of the medicinal plant species were distributed in 3 out of 15 sampled plots. Causal factors included over misuse of therapeutic plant species, habitats destruction and absence of proper conservation education of the masses. Recommendations are that Communities should set up therapeutic plants farms, enrichment planting be made in agricultural fields and sustainable harvesting methods used.
\end{abstract}

\section{Keywords}

Medicinal Plants, Ailments, Treatment, Cross River

\section{Introduction}

The use of plants as medicine otherwise known as traditional medicine (TM), dates as far back as the origin of human kind. Prior to the advent of Western science, medicinal practices as applied to man were probably very similar in all 
parts of the World, Food and Agriculture Organization (FAO, 1985).

The art of healing consisted of two main elements that were often used in combination: the application of natural products and an appeal to spiritual forces. African traditional medicine is the oldest and perhaps the most diverse of all medicine systems (Ekeanyanwu, 2011). The traditions of collecting plants as well as processing herbal remedies and applying them have been handed down from generation to generation. In the past two decades, there has been a world resurgence of interest in traditional medicine for the treatment of ailments that defy orthodox medicine (ailments of utmost native importance) primarily because many diseases developed resistance to conventional drugs hence these ailments are better treated with the use of medicinal plants. Fracture and dislocation for instance have led to patients at discharge after treatment with conventional drugs suffers periodic pains in the affected parts. The climax of it is situations whereby metallic structures are built into human legs to provide needed strength but suffers total collapse after series of years.

Pile patients have suffered repeated surgical operation of pile culminating in diagnosis of cancer and eventual death of the individuals. Within the area less than Five percent of patients who suffer from mile stroke end up having their limbs malfunctioning, faces twisted and deformed with their voices ceased at their discharged from the hospitals.

Women threatened with infertility and gynaecological problems, who exclusively rely on conventional medications with huge amount expended are commonly observed at most times unable to bear children. The above are as a result of resistances to conventional treatment.

As a result of this revival in unorthodox medicine, a lot of interest and attention have been drawn to the curative claims and norms (ethics) of herbal plants in different parts of the world especially Africa and Asia. In spite of the medicinal value of these plants to man, their uses for the treatments of sickness mostly at the primary stage of infestation are not well documented in Nigeria, especially in Cross River State. Knowledge of traditional medicine is still being passed by word of mouth from one generation to the subsequently by priests and medicine men. This may be that, there is no indigenous information about their uses, as most parents or herbalists die with the information owing to lack of interest of the present generation in practicing traditional medicine. When environmental degradation is mention little or no attention is given to the population of medicinal plants, not even by the Trado-medical Health Practitioners (THP). Generally, the medicinal plants species are becoming very scarce such that some THP when consulted for treatment decline due to difficulties in coming by the herbs for such treatment.

Sequel to the aforementioned challenges and potentials facing the use of herbal medicine in Cross River State this paper seeks to provide baseline knowledge on medicinal plants used for the treatment of "ailments of utmost native importance" including bone dislocation/fracture, snake bite, pile, partial stroke and 
infertility and gynaecological problems by trado-medical herbal practitioners (THP) in Cross River State, document their knowledge, preserve them in the event of their dead, ascertain their status and distribution as well as look at sustainable management of the medicinal plants in the state.

\section{Methods}

\section{Study Area}

Cross River State is made of eighteen neighborhood government ranges. The state lies between longitudes $7^{\circ} 40^{\prime \prime}$, and $9^{\circ} 50^{\prime \prime}$ East of the Greenwich Meridian and scopes $4^{\circ} 40^{\prime \prime}$, and $7^{\circ} 00^{\prime \prime}$ North of the Equator. It has a stormy season from April until October, amid which $80 \%$ of the yearly rain falls with tops in June and September. The yearly precipitation midpoint is 1830 millimeters (72 in). Normal temperatures extend from $24^{\circ} \mathrm{C}\left(75^{\circ} \mathrm{F}\right)$ in August to $30^{\circ} \mathrm{C}\left(86^{\circ} \mathrm{F}\right)$, in February, with high relative dampness in the vicinity of $80 \%$ and $100 \%$.

The State comprises of all vegetation zones of Nigeria except the Sahel. The vegetation ranges from mangrove swamps, through rainforest, to derived savanna, and montane parkland. The waterfront wetlands of the mangrove are intertwined with streams, montane parkland on the Obudu Plateau, virgin rainforest on the Oban-Obudu slopes, and derived Savanna on the Cross River Plain. Though, a considerable part of the land is made of the high forest, obviously most areas are experiencing rigorous dilapidation.

Cross River State is principally made up of farmers with more than $70 \%$ of the residents occupied in agricultural activities (Essoka, 2008). The population increased from 1,911,297 in 1991 to 2,892,988 in 2006 made of 1,471,967 males and 1,421,021 females. (Figure 1).

\section{Data Collection}

The data for this study were collected using field work and in depth oral interviews. The ethno botanical survey team comprised of two species identifiers (Taxonomists), two survey assistants, two field attendants, five trado-medical herbal practitioners and the Authors. From a reconnaissance survey conducted across the state, five Trado-medical Herbal Practitioners (THP) based on their competence in treating the "ailments of utmost native importance" were selected and their corresponding five Local Government Areas used for sampling. Three sample plots with each measuring $30 \mathrm{~m} \times 30 \mathrm{~m}$ were established in each local government area sampled. The sample plots were purposively laid at forested regions of the local government areas from where herbs are collected and their coordinates obtained following the method by (Ebu, 2016).

Two Taxonomists, the herbal practitioner and the Authors identified the plant species, classified the species into families and forms, with emphasis on their status and distribution in the study area as contained in Table 1 and Table 2. For Ogoja L.G.A., sample plots were laid at Abakpa, Ekpogrinya and Mbube Communities. 


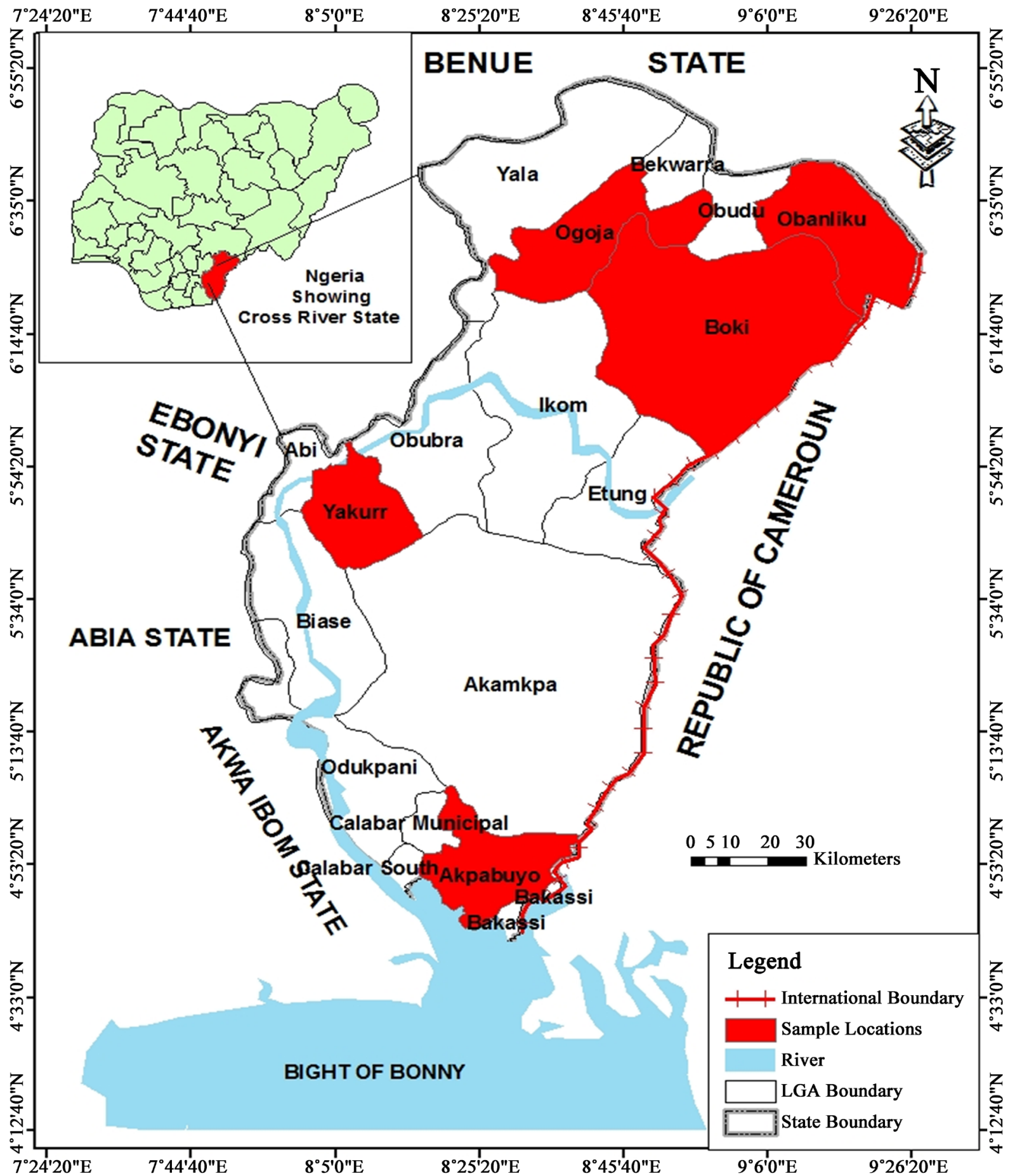

Source: Geographic Information System (GIS) Laboratory, Department of Geography and Environmental Science, University of Calabar.

Figure 1. Map of Cross River State showing the sample LGAs.

For Obanliku L.G.A., sample plots were laid at Begiesung, Amunga and Barga Communities. In Boki L.G.A, the sample plots were laid in Wula, Katabang and Abu Communities. In Yakurr L.G.A. the Communities used were Nko, AgoiIbami and Ugep and lastly for Akpabuyo L.G.A. the sample plots were laid at Ikot Edem Ndarake, Ikot Asuquo Edem and Ikot OffiongAngba Communities. Pro- 
gressively, a total of 15 sample plots were laid and all the different medicinal plants species encountered used in treating the "ailments of utmost native importance" were identified, tallied and documented.

The essence was to ascertain how common, scarce or extinct the medicinal plant species were and their pattern of distribution so as to know where they could be obtained when needed and possible sustainable measures to be employed. After the field work, all plant species that could not be immediately identified or whose identifications were in doubt were taken for confirmation/identification at the Forestry Herbarium, University of Calabar. In addition, Akobundu and Agyakwa (1998); Odugbemi (2006) and Etukudo (2003) were consulted for other taxonomic clarifications for the different plants. Laboratory (proximate and antinutrients) analyses were employed to investigate the phytochemicals responsible for the therapeutic functions of the plant species investigated (Ebu et al., 2019). The conservationist consulted included Incumbent and Emeritus Chairmen of Forestry Commission, Incumbent and Past Permanent Secretaries of Forestry Commission, Directors in Forestry Commission and Ministry of Environment and the Indigenous Conservationist who include farmers, hunters, resident in the area and very conversant with the vegetation were interviewed during the dry season and raining season.

\section{Results}

It was noted that a single plant had the capability of providing a vast array of remedy to different ailments. Khaya ivorensis and Afromomum malequeta were found to be the more commonly used plant species among the herbal practitioners who participated in the field work. Khaya ivorensis was used in the treatment of snake bite, partial stroke and infertility and gynaecological problems while Afromomum malequeta was used in treating snake bite and partial stroke.

For the treatment of dislocation and fracture three plant species belonging to two families were used, in all the three species only the leaves were used. For the treatment of snake bite three plant species belonging to three families were used, of which leaves of two of the species and seed of the third species were the parts used. For herbal treatment of partial stroke, five plant species belonging to five families were used the parts used included bark, seeds, leaves and stems. With regards to the medicinal plants for the treatment of pile two species of different families were used, parts used for the treatment were leaf and fruit. Tackling infertility and gynaecological problems in women, seven plant species were mentioned, which included Anthacleistad jalonensis, Khaya ivorensis, Caladium bicolour, Pipterdeniastrum africana, Triclisiasub cordata, Acanthus montanus and Alstonia boonei. The plant species belonged to seven different families, to one of the species, both the bark and leaf were used, to another the root was used; while to two other species the barks were used and to the last three species the leaves were used, Table 1. 
V. T. Ebu et al.

Table 1. Medicinal plant species for treatment of ailments of utmost native importance.

\begin{tabular}{|c|c|c|c|}
\hline Species Name & Form & Family & Part Used \\
\hline \multicolumn{4}{|l|}{ Dislocation/Fracture } \\
\hline Harungana madasgascariensis & Shrub & Hypericaceae & Leaves \\
\hline Anielema beniniense & Herb & Commelinaceae & Leaves \\
\hline Ipomoea involucrata & $H e r b$ & Convolrucaceae & Leaves \\
\hline \multicolumn{4}{|l|}{ Snake bite } \\
\hline Colocassia esculenta & Herb & Araceae & Leaves \\
\hline Khaya ivorensis & Tree & Maliaceae & fresh leaves \\
\hline Afromamum melequeta & $H e r b$ & Zingiberaceae & Seed \\
\hline \multicolumn{4}{|l|}{ Partial stroke } \\
\hline Cylicodiscus gabonensis & Tree & Leguminosae & Bark \\
\hline Afromomum melequeta & Herb & Zingibereceae & Seed \\
\hline Khaya ivorensis & Tree & Maliaceae & Bark \\
\hline Sarcocephalus latifolius & Tree & Naucleae & Leaves \\
\hline Ceiba pentandra & Tree & Bombaceae & Stem \\
\hline \multicolumn{4}{|l|}{ Pile } \\
\hline Ocimum gratissimum & $H e r b$ & Labiatae & Leaves \\
\hline Citrus limon & Tree & Rubeaceae & Fruit \\
\hline \multicolumn{4}{|c|}{ Infertility and Gynacological Problems } \\
\hline Anthacleista djalonensis & Tree & Loaniaceae & Root \\
\hline Khaya ivorensis & Tree & Maliaceae & Bark \\
\hline Caladium bicolour & Herb & Araceae & Leaves \\
\hline Pipterdeniastrum africana & Tree & Lepidobotryaceae & Bark \\
\hline Triclisia subcordata & Herb & Menuspemaceae & Leaves \\
\hline Acanthus montanus & $H e r b$ & Acanthaceae & Leaves \\
\hline Alstonia boonei & Shrub & Apocynaceae & Bark and leaves \\
\hline
\end{tabular}

Source: Field work 2016.

\section{Discussion}

A critical look at the checklist Table 2 reveals that 17 medicinal plant species belonging to 16 families were used in the treatment of the five ailments of utmost native importance investigated. This number is seen to be very small compared to 18 medicinal plant species for malaria (Dike \& Obembe, 2010) and 30 for Diabetes mellitus (Arowosegbe et al., 2015). Though Alstonia boonei, Anthacleista djalonensis, Citrus limon, Khaya ivorensis had been reported for Diabetes mellitus as in Harungana madagascariensis, Afromomum melequeta and Khaya ivorensis were reported for viral diseases (Oladunmoye \& Kehinde, 2011) and Harungana madagascariensis was reported for women related disease in Nigeria (Olanipekun et al., 2016) this is the first detail regarding the traditional use 
Table 2. Status and Distribution of Identified Medicinal Plants Species of Ailments of Utmost Native Importance in the Study Area.

\begin{tabular}{|c|c|c|c|c|c|c|c|c|c|c|c|c|c|c|c|c|c|}
\hline \multirow[b]{2}{*}{$\mathrm{S} / \mathrm{N}$} & \multirow[b]{2}{*}{ Species } & \multicolumn{3}{|c|}{ OGOJA } & \multicolumn{3}{|c|}{ OBANLIKU } & \multicolumn{3}{|c|}{ BOKI } & \multicolumn{3}{|c|}{ YAKURR } & \multicolumn{3}{|c|}{ AKPABUYO } & \multirow[b]{2}{*}{ Frequency } \\
\hline & & $\begin{array}{l}\stackrel{0}{0} \\
\stackrel{z}{\Sigma}\end{array}$ & 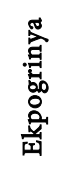 & 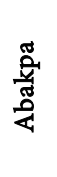 & 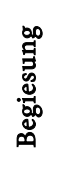 & $\begin{array}{l}\text { 品 } \\
\text { 元 } \\
\text { 完 }\end{array}$ & 莺 & $\frac{\pi}{3}$ & 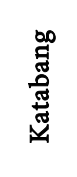 & 荌 & 总 & : & 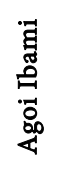 & 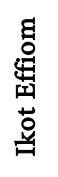 & 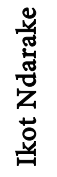 & 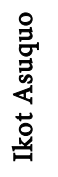 & \\
\hline 1 & $\begin{array}{c}\text { Harunguna } \\
\text { Madasgascariensis }\end{array}$ & $\mathrm{R}$ & & & & & & & $\mathrm{R}$ & & & & & & & & 33 \\
\hline 2 & Anielema beniniense & & & & & & & $\mathrm{R}$ & $\mathrm{R}$ & $\mathrm{R}$ & & & $\mathrm{E}$ & & $\mathrm{E}$ & & 32 \\
\hline 3 & Ipomoea involucrata & & & & & & & & $\mathrm{C}$ & $\mathrm{C}$ & & & $\mathrm{R}$ & & & & 118 \\
\hline 4 & Colocassia esculenta & & & & & & & & & & & & & & & & NF \\
\hline 5 & Khaya ivorensis & & & & & & & & $\mathrm{E}$ & $\mathrm{E}$ & & & & & & & 6 \\
\hline 6 & Afromomum melequeta & & & & & & & & & & & & & & & & NF \\
\hline 7 & Cylicodiscus gabonensis & & & & & & & & E & & & & & & & & 6 \\
\hline 8 & Sarcocephalus latifolius & $\mathrm{C}$ & & & & & & & & & & & & & & & 66 \\
\hline 9 & Ceiba pentandra & & & & $\mathrm{E}$ & & & $\mathrm{E}$ & & & & & & & & & 6 \\
\hline 10 & Ocimum gratissimum & & & & & & & & & & & & $\mathrm{C}$ & & & & 75 \\
\hline 11 & Citrus limon & & & & & & & & & & $\mathrm{E}$ & & & & & & 6 \\
\hline 12 & Anthacleista djalonensis & & & & & & & & $\mathrm{E}$ & $\mathrm{E}$ & & & $\mathrm{E}$ & $\mathrm{E}$ & $\mathrm{E}$ & $\mathrm{E}$ & 13 \\
\hline 13 & Caladium bicolour & & & & & & & $\mathrm{E}$ & E & $\mathrm{R}$ & & $\mathrm{R}$ & & & & & 110 \\
\hline 14 & Pipterdeniastrum africana & & & & & & & & $\mathrm{E}$ & $\mathrm{E}$ & & & & & & & 12 \\
\hline 15 & Triclisia subcordata & & & & & & & & C & $\mathrm{C}$ & & & & $\mathrm{R}$ & $\mathrm{C}$ & $\mathrm{R}$ & 247 \\
\hline 16 & Acanthus montanus & & & & & & & $\mathrm{R}$ & C & $\mathrm{C}$ & & & $\mathrm{R}$ & & $\mathrm{R}$ & & 113 \\
\hline 17 & Alstonia boonei & & & & & & & & & & & & & $\mathrm{E}$ & $\mathrm{E}$ & $\mathrm{E}$ & 19 \\
\hline
\end{tabular}

Source: Field work, 2016. NF = Not found, $\mathrm{R}=$ Rare, $\mathrm{C}=$ Common, $\mathrm{E}=$ Endanger.

of Harungana madagascriensis, Anielema beniniense and Ipomoea involucrata in the treatment of dislocation/fracture.

Again no mention had been made of Colocassia esculenta in the treatment of snake bite, nor Cylicodiscus gabonensis, Sarcocephalus latifolius and Ceiba pentandra mentioned in the treatment of partial stroke except in this study. This point to the fact that due to variation in indigenous knowledge, people could be sick while living in the midst of herbs that could cure such ailments but because of the lack of indigenous knowledge of their curative potentials, they stay in pains pending when they are able to find medicinal plant species to which they are familiar with.

The use of identified medicinal plant species for the treatment of snake bite was in conformity with the statements of (Martz, 1992; Houghton \& Osibogun, 1993) that, indigenous systems of medicine used medicinal plants with huge repository anti-snake venom activity for the treatment of snake bites. 
The study evidenced that therapeutic plant species utilized in the treatment of partial stroke rhymed with several published works on the effects and possible benefits of traditional medicine in stroke management (Kim, 2005; Gong \& Sucher, 2003; Zeng et al., 2005). The treatment of pile with the use of Ocimumgratissimum and citrus lemon are in alliance with the findings of (Borokini et al., 2013).

By coincidence Ocimum gratissimum appeared very prominent in the treatment of pile from the indigenous knowledge in Cross River State and that of Oyo state. Status and geographical distribution of the identified medicinal plant species investigated was more appalling. Of the 17 medicinal plant species identified, 59 percent of them were distributed in 3 out of 15 sampled plots. This was indicative of degradation and loss of these plant species within the sampled forest ecosystem.

From the oral interview conducted with Conservationists and Herbal Practitioners, it was gathered that medicinal plant species were on the decline, with many becoming rare, others endangered and others extinct. Some of the evidences gathered included the inability to treat some ailments as a result of lack of their herbs which may have been loss by virtue of over exploitation, deforestation or unsustainable harvesting methods.

The biggest threat to medicinal plant species was found to be the incessant use of fire and herbicides on the vegetation. While fire was used in the dry season, herbicides were widely used on farms and plantations in the wet season. From the interview, the factors responsible for the depletion of medicinal plant species were summarized and included: Over-misuse of therapeutic plant species, habitat destruction, absent of proper conservation education of the Masses. Typical of such lack of proper conservation education for instance, have led to the removal of the bark of several stems of Pipterdeniastrum africanum and Cylicodiscus gabonensis resulting in their dead. One of the prominent effect of the decline in the population of this medicinal plant as guarded from the THP was their momentary decline attending to patient when consulted. Alternatively, consultations are done at higher costs considering the difficulties in coming by the medicinal plant.

\section{Conclusion}

Species diversity was found to be most in Boki and Yakurr local government areas containing forest tree species. The medicinal species rather than being in abundance were rare in almost all the Local Government Areas. Citrus limon was not found anywhere.

The major factors responsible for the decline in medicinal species population were found to be forest clearance for farming and urban development. Removal of bark from stems of Pipterdeniastrum africanum and Cylicodiscus gabonensis is partly responsible for their low population. The reduction in the population of medicinal plant is making the treatment process undependable, as the species are very difficult to come by. 


\section{Recommendations}

Communities should set up therapeutic plants plantations as a type of participatory way to deal with reasonable protection and security of medicinal plants which will perhaps control overexploitation that undermines forests and the general population subordinate upon them as was applicable to Citrus limon and Ocimum gratisimum. Additionally consolidating medicinal plants in agricultural fields will help incredibly to expand supply and preservation of imperative therapeutic plants in the review regions. Furthermore, it is hereby stressed that for sustainable utilization of the medicinal plant species, better harvesting methods should be employed for, instance, the removal of the barks of Pipterdeniastrum africanum and Cylicodisus gabonensis should be made alternately to avoid the tree dying on peeling it round. In all homestead, medicinal plant species should be incorporated.

\section{Conflicts of Interest}

The authors declare no conflicts of interest regarding the publication of this paper.

\section{References}

Akobundu, I. O., \& Agyakwa, I. (1998). A Handbook of West African Weeds (564 p). International Institute of Tropical Agriculture.

Arowosegbe, S., Olanipekun, M. K., \& Kayode, J. (2015). Ethnobotanical Survey of Medicinal Plants Used for the Treatment of Diabetes Mellitus in Ekiti South Senatorial District, Nigeria. European Journal of Botany, Plant Sciences and Phytology, 2, 1-8.

Borokini, T. I., Ighere, D. A., Clement, M., Ajiboye, T. O., \& Alowonle, A. A. (2013). Ethnobiological Survey of Traditional Medicine Practice for the Treatment of Piles and Diabetes Mellitus in Oyo State. Journal of Medicinal Plants Studies, 1, 30-40.

Dike, I. P., \& Obembe O. O. (2010). Towards Conservation of Nigerian Medicinal Plants. Journal of Medicinal Plants Research, 6, 3517-3521. https://doi.org/10.5897/JMPR10.612

Ebu, V. T. (2016). Trado-Medical Utilization of Medicinal Plants in Cross River State, Nigeria. Unpublished Doctoral Thesis, University of Calabar.

Ebu, V. T., Mgbang, J. E., \& Bukie, J. O. (2019). Anti-Nutrient Contents of Herbs Used in the Treatment of "Ailments of Utmost Native Importance" in Cross River State, Nigeria. Journal of Agriculture, Forestry and Social Sciences, 9, 175-182.

Ekeanyanwu, C. R. (2011). Traditional Medicine in Nigeria: Current Status and the Future. Research Journal of Pharmacology, 5, 90-94.

Essoka, P. A. (2008). Soil Variation over Basement Complex Rocks and Slope Position in a Part of Cross River Plains, South Eastern Nigeria. Unpublished Doctoral Thesis, Amadu Bello University.

Etukudo, I. (2003). Ethnobotany: Conventional and Traditional Uses of Plants (191 p). Micro-Bit Systems.

Food and Agriculture Organization of the United Nations (1985). The State of Food and Agriculture 1984. World Review: The Ten Years the World Food Conference, Rome, 1 March 1985, 209.

Gong, X., \& Sucher, N. J. (2002). Stroke Therapy in Traditional Chinese Medicine (TCM): 
Prospects for Drug Discovery and Development. Phytomedicine, 9, 478-484. https://doi.org/10.1078/09447110260571760

Houghton, P. J., \& Osibogun, I. M. (1993). Flowering Plants Used Against Snakebite. Journal of Ethnopharmacology, 39, 1-29. https://doi.org/10.1016/0378-8741(93)90047-9

Kim, H. (2005). Neuroprotective Herbs for Stroke Therapy in Traditional Eastern Medicine. Neurological Research, 27, 287-301. https://doi.org/10.1179/016164105X25234

Martz, W. (1992). Plants with a Reputation against Snakebite. Toxicon, 30, 1131-1142. https://doi.org/10.1016/0041-0101(92)90429-9

Odugbemi, T. (2006). Outlines and Pictures of Medicinal Plants from Nigeria (pp. 95-156). University of Lagos Press.

Oladunmoye, M. K., \& Kehinde, F. Y. (2011). Ethnobotanical Survey of Medicinal Plants Used in Treating Viral Infections among Yoruba Tribe of South Western Nigeria. African Journal of Microbiology Research, 5, 2991-3004.

https://doi.org/10.5897/AJMR10.004

Olanipekun, M. K., Arowosegbe, S., Kayode, J. O., \& Oluwole, T. R. (2016). Ethnobotanical Survey of Medicinal Plants Used in the Treatment of Women Related Diseases in Akoko Region of Ondo-State, Nigeria. Journal of Medicinal Plants Research, 10, 270 277.

Zeng, X., Liu, M., Yang, Y., Li, Y., \& Asplund, K. (2005). Ginkgo Biloba for Acute Ischaemic Stroke. Cochrane Database of Systematic Reviews 2005, 2005, Article No. CD003691. 